\title{
Determination of Plant Density on Yield of Sorghum Intercropping with Haricot Bean at Fadis and Babile
}

\author{
Habte Berhanu Umata ${ }^{1 *}$, Adugna Hunduma Debelo ${ }^{2}$ \\ ${ }^{1}$ Researcher, Plant Science, Fadis Agricultural Research Center, Harar, ETHIOPIA \\ ${ }^{2}$ Researcher, Agronomy, Fadis Agricultural Research Center, Harar, ETHIOPIA \\ ${ }^{*}$ Corresponding Contact: \\ Email: habtiyebirish@gmail.com
}

\begin{abstract}
Haricot bean is a principal food crop particularly in Southern and Eastern part of Ethiopia, where it is widely intercropped with maize and sorghum, respectively, to supplement farmer's income (EPPA, 2004). This experiment was handling the appropriate seeding rate on yield of sorghum and haricot bean grown with intercropping system at Eastern Hararghe areas. This activity was done at two locations, Babile and Fadis in RCBD design. The research result showed that, there was significance difference among treatments. treatment (25cmsorghum $* 30 \mathrm{cmharicotbean)}$ and $(30 \mathrm{cmsorghum}$ and $30 \mathrm{cmharicotbean}$ ) have more yield when compared to the other both in terms of yield and land equivalent ratio .Even though the sole sorghum yield per hectare were relatively looks like high, the cumulative yield of intercropping yield were higher than the sole sorghum. At both location (Fadis and Erer) the data obtained were similar. This indicates that similar recommendation for the two locations.
\end{abstract}

Keywords: sorghum, Haricot bean, intercropping and land equivalent ratio

$4 / 23 / 2017$

Source of Support: Nil, No Conflict of Interest: Declared

This article is is licensed under a Creative Commons Attribution-NonCommercial 4.0 International License.

Attribution-NonCommercial (CC BY-NC) license lets others remix, tweak, and build upon work non-commercially, and

although the new works must also acknowledge \& be non-commercial.

\section{INTRODUCTION}

Sorghum (Sorghum bicolor (L.) Moench) and common bean (Phaseolus vulgaris L.) are commonly intercropped in low moisture areas of Ethiopia. Although, Europeans considered sorghum as the 'poor man's crop' of Africa and Asia (Tenebe and Kamara, 2002), it is the fifth most important cereal crop worldwide in both planted area and metric tons harvested (FAOUN, 2003). Seventy eight percent of sorghum harvested area lies within Africa and Asia. In the semi-arid Africa, the crop is the leading food grain for millions and it is deep rooted in the culture and traditions of the people. In addition, the crop has an agronomic performance that resists abiotic and biotic stresses (Berenji and Dahlberg, 2004). However, the crop is under subsistence agriculture and associated with the drier and hotter parts of the continent where growing environment are marginal for other twelve pulse species are grown in the country. Of these, faba bean (Vicia faba L.), 
field pea (Pisum sativum L.), chickpea (Cicer arietinum L.), lentil (Lens cultinaris Medik.), grass pea (Lathyrus sativus L.), fenu greek (Trigonella foenum-graecum L.) and lupine (Lupinus albus L.) are categorized as highland pulses and grown in the cooler highlands. Conversely, haricot bean (Phaseolus vulgaris L.), soya bean (Glycine max L.), cowpea (Vigna unguiculata L.), pigeon pea (Cajanus cajan L.) and mung beans are predominantly grown in the warmer and low land parts of the country. Among the individual varieties, faba beans (broadly known as horse beans) accounts for the greatest portion of production at 36 percent, followed by haricot beans (17 percent) and chickpeas (16 percent). Other pulses (e.g., lentils, peas, lupines, and mung beans) account for the remaining 32 percent (Rashid and Lemma 2010), cereals such as maize (Yilma and Brhane, 1979).

Among legumes, haricot bean, Phaseolus vulgaris, constitute a significant part of human diet in Ethiopia (Ali et al., 2003). Apart from this, haricot bean has been cultivated as a field crop for a very long time and hence, it is the important food legume produced in the country (Ali et al., 2003). Haricot bean is a principal food crop particularly in Southern and Eastern part of Ethiopia, where it is widely intercropped with maize and sorghum, respectively, to supplement farmer's income (EPPA, 2004). This experiment was handling the appropriate seeding rate on yield of sorghum and haricot bean grown with intercropping system at proposed areas.

\section{Methodology}

This activity was done at two locations, Erer and Fadis in RCBD design. For the first cropping year (2003 E C) it was better performed at Fadis but not at Erer due to uninform germination which lead to poor harvesting. For the second cropping year (2004 E C) it was better performed at both location, Erer and Fadis

The treatment used were: Sorghum $\mathbf{x}$ Haricot bean intercropping (intra spacing)
1. $25 \times 30 \mathrm{~cm}$
5. $30 \times 30 \mathrm{~cm}$
9. $35 \times 30 \mathrm{~cm}$
13. Sole haricot bean
2. $25 \times 35 \mathrm{~cm}$
$6.30 \times 35 \mathrm{~cm}$
$10.35 \times 35 \mathrm{~cm}$
14. Sole sorghum
3. $25 \times 40 \mathrm{~cm}$
7. $30 \times 40 \mathrm{~cm}$
$11.35 \times 40 \mathrm{~cm}$
4. $25 \times 45 \mathrm{~cm}$
$8.30 \times 45 \mathrm{~cm}$
12. $35 \times 45 \mathrm{~cm}$

Two rows of haricot bean were intercropped in one row of sorghum at $25 \mathrm{~cm}$ apart from sorghum row and haricot bean row. The recommended fertilizer rate was used. All field and crop management was done as per required. Gen STAT software was used for data analysis. 


\section{RESULt ANd Discussion}

Table 1: Effect of intra row spacing on sorghum and haricot bean intercropping at Fadis in 2004 and 2005.

\begin{tabular}{|c|c|c|c|c|c|c|c|c|c|c|}
\hline & \multicolumn{5}{|c|}{2004} & \multicolumn{5}{|c|}{2005} \\
\hline Treatments & $\begin{array}{l}\text { Stand } \\
\text { count }\end{array}$ & $\begin{array}{l}\text { Panicle } \\
\text { length }\end{array}$ & $\begin{array}{l}\text { Tillering } \\
\text { capacity }\end{array}$ & $\begin{array}{c}\text { Sorghum } \\
\text { (kg/ha) }\end{array}$ & \begin{tabular}{|l|} 
Haricot \\
$(\mathrm{kg} / \mathrm{ha})$
\end{tabular} & $\begin{array}{l}\text { Stand } \\
\text { count }\end{array}$ & $\begin{array}{l}\text { Panide } \\
\text { lenght }\end{array}$ & \begin{tabular}{|l|} 
Tillering \\
capacity
\end{tabular} & $\begin{array}{l}\text { Sorghum } \\
\text { (kg/ha) }\end{array}$ & $\begin{array}{l}\text { Haricot } \\
\text { (kg/ha) }\end{array}$ \\
\hline \multicolumn{11}{|c|}{ Sorghum spacing } \\
\hline 25 & 46.0 & 22.08 & 5.50 & 1881 & 791 & 49.0 & 25.1 & 7.50 & 1890 & 850 \\
\hline 30 & 43.5 & 22.25 & 7.17 & 1705 & 817 & 45.7 & 25.50 & 8.70 & 1800 & 840 \\
\hline 35 & 37.3 & 23.08 & 6.17 & 1828 & 986 & 39.5 & 25.50 & 8.25 & 1858 & 996 \\
\hline LSDY0.05) & 6.17 & 0.89 & 2.94 & 254.1 & 190.5 & 7.07 & 1.09 & 2.99 & 259.1 & 198.5 \\
\hline $\mathrm{CV}(\%)$ & 4.5 & 4.7 & 55.4 & 16.6 & 26.0 & 6 & 5.6 & 50 & 18.5 & 27 \\
\hline \multicolumn{11}{|c|}{ Haricot bean spacing } \\
\hline 30 & 37.3 & 22,44 & 6.56 & 1670 & 933 & 40.5 & 26.40 & 8.50 & 1680 & 937 \\
\hline 35 & 46.8 & 22.00 & 5.78 & 1997 & 810 & 50.30 & 25.34 & 7.58 & 2005 & 815 \\
\hline 40 & 41.8 & 22.44 & 6.22 & 1724 & 964 & 44.4 & 26.40 & 8.20 & 1730 & 969 \\
\hline 45 & 43.2 & 23.00 & 6.56 & 1827 & 751 & 47.2 & 26.50 & 7.59 & 1831 & 756 \\
\hline LSD $(0.05)$ & 7.13 & 1.79 & 5.89 & 293.4 & 220.0 & 8.23 & 2.59 & 6.69 & 29730 & 225.0 \\
\hline CV $(\%)$ & & 4.7 & 55.4 & 16.6 & 26.0 & & 5.5 & 50.5 & 175 & 27.5 \\
\hline \multicolumn{11}{|c|}{ Cropping system } \\
\hline Solecropping & 49.00 & 24.00 & & 2081.3 & 1367.7 & 78.7 & 23.96 & 11.7 & 169.0 & 2244.4 \\
\hline Intercropping & 42.27 & 22.44 & & 1804.7 & 864.5 & 68.2 & 24.17 & 8.50 & 162.3 & 1885.2 \\
\hline $\operatorname{LSD}(0.05)$ & 10.65 & 1.32 & & 423.1 & 287.9 & 12.62 & 1.765 & 4.185 & 11.55 & 556.2 \\
\hline $\mathrm{CV}(\%)$ & 20.4 & 4.8 & & 19.0 & 26.1 & 15.0 & 6.0 & 39.2 & 5.8 & 23.8 \\
\hline
\end{tabular}

Table 2. Effect of intra row spacing on land equivalent ratio of sorghum and haricot bean intercropping at Fadis 2004.

\begin{tabular}{|l|c|c|c|}
\hline Treatments & $\begin{array}{c}\text { Sorghum } \\
(\mathrm{kg} / \mathrm{ha})\end{array}$ & $\begin{array}{c}\text { Haricot bean } \\
(\mathrm{kg} / \mathrm{ha})\end{array}$ & LER \\
\hline Sorghum spacing & & & \\
\hline 25 & 1881 & 791. & 1.542 \\
\hline 30 & 1705 & 817 & 1.482 \\
\hline 35 & 1828 & 986 & 1.611 \\
\hline LSD (0.05) & 254.1 & 190.5 & 0.222 \\
\hline CV (\%) & 16.6 & 26.0 & 17.0 \\
\hline Haricot bean spacing & & & \\
\hline 30 & 1670 & 933 & 1.536 \\
\hline 35 & 1997 & 810. & 1.556 \\
\hline 40 & 1724 & 964 & 1.588 \\
\hline 45 & 1827 & 751 & 1.500 \\
\hline LSD(0.05) & 293.4 & 220.0 & 0.2563 \\
\hline CV (\%) & 16.6 & 26.0 & 17.0 \\
\hline Cropping system & & & \\
\hline Sole cropping & 2081.3 & 1367.7 & 1.0000 \\
\hline Intercropping & 1804.7 & 864.5 & 1.5447 \\
\hline LSD (0.05) & 423.1 & 287.9 & $0.3076^{* *}$ \\
\hline CV (\%) & 19.0 & 26.1 & 16.8 \\
\hline
\end{tabular}


Table 3. Effect of intra row spacing of sorghum and haricot bean intercropping at Erer 2005

\begin{tabular}{|l|c|c|c|c|c|c|}
\hline Treatments & SC at TH & STC_atH & $\begin{array}{c}\text { Panicle } \\
\text { length }\end{array}$ & PH & $\begin{array}{c}\text { Sorghum } \\
(\mathrm{kg} / \mathrm{ha})\end{array}$ & $\begin{array}{c}\text { Haricot bean } \\
(\mathrm{kg} / \mathrm{ha})\end{array}$ \\
\hline \multicolumn{7}{|l|}{ Sorghum spacing } \\
\hline 25 & 40.1 & 68.1 & 8.00 & 155.8 & 2561 & 1263 \\
\hline 30 & 42.1 & 67.5 & 10.67 & 156.4 & 2328 & 739 \\
\hline 35 & 36.8 & 60.2 & 8.92 & 156.0 & 1823 & 1093 \\
\hline LSD (0.05) & 8.12 & 11.15 & 2.630 & 5.59 & $595.6^{*}$ & $136.0^{* *}$ \\
\hline CV (\%) & 24.2 & 20.2 & 33.8 & 4.2 & 31.4 & 15.6 \\
\hline Haricot bean spacing & 40.4 & 70.0 & 9.33 & 157.3 & 2555 & 1037 \\
\hline 30 & 37.6 & 60.8 & 8.44 & 150.8 & 2104 & 904 \\
\hline 35 & 36.6 & 57.0 & 8.44 & 155.0 & 1845 & 1230 \\
\hline 40 & 44.0 & 73.2 & 10.56 & 161.2 & 2445 & 957 \\
\hline 45 & 9.38 & 12.87 & 3.037 & 6.46 & 687.7 & $157.1^{* *}$ \\
\hline LSD(0.05) & 24.2 & 20.2 & 33.8 & 4.2 & 31.4 & 15.6 \\
\hline CV(\%) & \multicolumn{5}{|l|}{} \\
\hline Cropping system & 67.333 & 87.333 & 12.333 & 156.000 & 2689.0 & 866.7 \\
\hline Sole cropping & 39.639 & 65.250 & 9.194 & 156.083 & 2237.3 & 1031.7 \\
\hline Intercropping & $11.68^{* *}$ & $17.21^{*}$ & 4.254 & 8.653 & 928.5 & 450.8 \\
\hline LSD (0.05) & 22.9 & 21.1 & 37.0 & 4.5 & 33.5 & 36.3 \\
\hline CV (\%)
\end{tabular}

Note: *significant at $0.05 \%$ level of probability, ${ }^{* *}$ highly significant at 0.01 level of probability

Table 4. Effect of intra row spacing of sorghum and haricot bean intercropping on land equivalent ratio at Erer 2005

\begin{tabular}{|l|c|c|c|}
\hline Treatments & $\begin{array}{c}\text { Sorghum } \\
(\mathrm{kg} / \mathrm{ha})\end{array}$ & $\begin{array}{c}\text { Haricot bean } \\
(\mathrm{kg} / \mathrm{ha})\end{array}$ & LER \\
\hline Sorghum spacing & & & \\
\hline 25 & 2561 & 1263 & 1.958 \\
\hline 30 & 2328 & 739. & 1.544 \\
\hline 35 & 1823 & 1093. & 1.660 \\
\hline LSD (0.05) & $595.6^{*}$ & $136.0^{* *}$ & 0.2137 \\
\hline CV (\%) & 31.4 & 15.6 & 14.7 \\
\hline Haricot bean spacing & & & \\
\hline 30 & 2555 & 1037 & 1.767 \\
\hline 35 & 2104 & 904 & 1.611 \\
\hline 40 & 1845 & 1230 & 1.848 \\
\hline 45 & 2445 & 957 & 1.658 \\
\hline LSD(0.05) & 687.7 & $157.1^{* *}$ & 0.2468 \\
\hline CV (\%) & 31.4 & 15.6 & 14.7 \\
\hline Cropping system & & & \\
\hline Sole cropping & 2689.0 & 866.7 & 1.0000 \\
\hline Intercropping & 2237.3 & 1031.7 & 1.7097 \\
\hline LSD (0.05) & 928.5 & 450.8 & $0.4124^{*}$ \\
\hline CV (\%) & 33.5 & 36.3 & 20.4 \\
\hline
\end{tabular}

Note: *significant at $0.05 \%$ level of probability, ${ }^{* *}$ highly significant at 0.01 level of probability 


\section{Discussion}

\section{Stand count at harvest}

The analysis variance revealed that stand count was significantly affected due to main effect of sorghum population and haricot bean population. The highest stand count was recorded in narrow spacing while the lower population was recorded in wider spacing. Year by location shows similar result in Fadis. This might be due to number population per hectare and the research work in agreement with different research work. Similar trends were observed in Erer site. Cropping system significantly influence stands count at harvest. The highest stand count at harvest is recorded I sole cropping system while the lowest stand count at harvest was recorded in intercropping system. Intercropping system reduced the stand count at harvest by $14 \%$. This might be due to competition effect amount the crop.

\section{Panicle length}

The analysis of variance revealed that panicle length was not significantly affected due to main effect of sorghum population and haricot bean population. Year by location showed that no significant difference due to panicle length. Cropping system significantly influence panicle length of sorghum. The highest panicle length was obtained in sole sorghum (24) than the lowest was recorded in intercropping system (22.44). However, cropping system in 2005 in Fadis showed that no significant effect on panicle length of sorghum; this might be due to environmental change from year to year. Similar trends was observed in Erer.

\section{Tillering capacity (TC)}

The analysis of variance revealed that sorghum tillering capacity was not significant due to main effect of sorghum population and haricot bean population at both year in Fadis. Also tillering capacity was no significant due to main effect of sorghum population and haricot bean population at Erer location. This might be similar variety are similar responsible for tillering capacity even if the population of sorghum and intercropped hair cot bean increases or decreases.

\section{Sorghum yield $\mathrm{kg}$ ha -1}

The analysis of variance revealed that sorghum yield was significantly affected due to main effect of haricot bean population and non-significant difference was obtained in intercropping system. However highest sorghum grain yield was obtained in sole sorghum than intercropped sorghum. At Erer site sorghum grain yield significantly affected due to main effect of sorghum population and haricot bean population. No significant difference was recorded due intercropping system.

\section{Haricot bean yields kg ha-1}

The analysis of variance revealed that sorghum grain yield was significantly affected due to main effect of sorghum population density and haricot bean population density. cropping system significantly influence haricot bean population the highest haricot bean population was recorded in sole haricot bean while the lowest yield was obtained in intercropped haricot bean this might be due to competition effect of crops for nutrients , sun light and moisture. Similar result was obtained in 2005 at Erer Location (site). 


\section{LER}

Land equivalent ration was significantly affected due to main effect of sorghum population density and haricot bean population density the highest LER was recorded due to cropping system the highest LER was recorded in intercropping system while the lowest was recorded in sole cropping system at all location.

\section{RECOMMENDATION}

The research result showed that, there was significance difference among treatments (table $1)$. treatment $1\left(25 \mathrm{~cm}^{\text {sorghum } * 30 \mathrm{~cm}^{\text {haricotbean }}}\right)$ and $2\left(30 \mathrm{~cm}^{\text {sorghum }}\right.$ and $\left.30 \mathrm{~cm}^{\text {haricotbean }}\right)$ have more yield when compared to the other both in terms of yield and land equivalent ratio .Even though the sole sorghum yield per hectare were relatively looks like high, the cumulative yield of intercropping yield were higher than the sole sorghum. At both location (Fadis and Erer) the data obtained were similar. This indicates that similar recommendation for the two locations.

\section{REFERENCES}

Activity of Soy Bean Exposed to Fixed Nitrogen. Plant Physiology, 70: 1236-1241.

Ali, K., Keneni, G., Ahmed, S., Melhotra, R., Beniwal, S., Makkout, K., and Halila, M. H., 2003. "Food and forage legumes of Ethiopia: Progress and Prospects.Proceedings of The Workshop On Food and Forage Legumes 22-26 September 2003, Addis Ababa, Ethiopia. Sponsors: EIAR and ICARDA." International Center for Agricultural Research in the Dry Areas (ICARDA), Aleppo, Syria. p: 351.

Berenji, J. and Dahlberg, J. (2004), Perspectives of Sorghum in Europe. Journal of Agronomy and Crop Science, 190: 332-338. doi:10.1111/j.1439-037X.2004.00102.x

Davis, J.H.C., and S. Garcia, 1983. Field Crops research 6: 59-75. In: Ofori, F. and Stern,

De Haan, R.L., C.C. Sheaffer, D.A. Samac, J.M. Maynihan, and D.K. Barnes, 2002.

Dechasa Hirpa, 2005. Effect of moisture conservation methods \& Plant Density of Component Crops on Performance of Sorghum/bean intercropping in Meiso district, West Hararghe. M.Sc. Thesis, Alemaya University.

Dechasa Olani, 1996. Relative Performance of haricot bean genotypes in Sole and Sorghum intercropped systems. M.Sc. Thesis, Alemaya University of Agriculture

Effect of intercropping on nodulation and N2-fixation by groundnut. Experimental Agriculture, 19: 79-86.

EPPA (Ethiopian Pulses Profile Agency). 2004. Ethiopian Export Promotion Agency Product Development \& Market Research Directorate, Ethiopia.

Evaluation of annual Medicago for upper Midwest Agro-ecosystems. Journal of Agronomy and Crop Scences, 188: 417-425.

Ibrahim, Y.M., M.O. Gaffer and D.A.A. Wahab. 1993. Intercropping of pioneer sorghum with lablab purpureus (1.) under irrigation at shambat. Annals of Arid Zone, 32(3): 157-159.

ICRISAT. 1980. Annual Report for 1978-79. International Crop Research Institute for Semiarid tropics, Hayderabad.

MARC (Mekelle Agricultural Research Center). 1998. Annual Report, 1997-98. Mekelle, Ethiopia.

McCollum, R.E. 1982. Expert consult. Fertilizer use multiple cropping System. FAO, 1-6 Feb., New Dlhi.

Mead, R. and R.W. Willey. 1980. The concept of a 'Land Equivalent Ratio' and advantages in yields from intercropping. Experimental Agriculture, 16: 217-28.

MoARD (Ministry of Agriculture and Rural Development). 2005. Crop Development Department. Issue No. 8. Addis Ababa, Ethiopia.

Moll, R.H., E.J. Kamprath and W.A. Jackson. 1982. Analysis and interpretation of factors which contribute to efficiency of N utilization. Agronomy Journal, 74:562-564. 
Nambiar, P.T.C., M.R. Roa, M. S. Raddy, C.N. Floyd, P.J. Dart and R.W. Willey. 1983.

Natarjan, M. and R.W. Willey. 1980. Sorghum pigeon-pea Intercropping and the effects of plant population density. II. Resource use. Journal of Agricultural Science, 95: 51-58.

Natrajan, M. and R.W. Willey. 1980. Sorghum pigeon pea intercropping and the effect of plant population density. Journal of Agricultural Science, 95: 51-58.

Noel, K.O., M. Carneol and W.J. Brill. 1982. Nodule Protein Synthesis and Nitrogenase

Ofori, F. and W. R. Stren. 1987. Cereal/legume intercropping systems. Advances in Agronomy, 41: 41-90.

Osiru, D.S.O. and R.W. Willey. 1972. Studies on mixture of dwarf sorghum and beans (paseolus vulgaris) with particular reference to plant population. Journal of Agricultural Science, 79: 531-540.94

Rashid, S., and S. Lemma. 2010. Strategic Grain Reserve in Ethiopia: Institutional Design and Operational Performance. IFPRI Discussion Paper 1054. Washington, D.C.: International Food Policy Research Institute.

Tamado Tana and Eshetu Mulatu. 2000. Evaluation of Sorghum, Maize and Common Bean Cropping System in East Hararghe, Eastern Ethiopia. Ethiopian Journal of Agricultural Science, 17: 33-45.

Tenebe V. A. and Kamara H. M. (2002) Effect of Striga hermonthica on the Growth Characteristics of Sorghum Intercropped with Groundnut VarietiesVolume 188, Issue 6, pages 376-381, December 2002

W.R. 1987. Cereal/legume intercropping systems. Advances in Agronomy, 41: 41-90. 63

Yesuf Mohammed. 2003. Effect of Planting Arrangement and Population Densities of Haricot Bean on Productivity of Sorghum/Haricot Bean Additive Mixtures. M.Sc. Thesis, Alemaya University, Alemaya, Ethiopia. 80p

Yilma K, Brehane G (1979). Some important diseases of sorghum in Ethiopia Scientific Phytopathological Laboratory (SPL). Paper presented to the First Conference of Diseases, Pest, and Weeds of Cereal and Horticultural Crops in Ethiopia and Methods of their control. IAR June 1979. Ambo, Ethiopia, pp. 12-18. 
